Annals of Plant and Soil Research 22(4): 361-366 (2020)

https://doi.org/10.47815/apsr.2020.10005

\title{
Status of macro- and micro-nutrients in soils of Chamoli district of Uttarakhand
}

\section{SAYANTIKA BHATTACHARYA, S.P. PACHAURI* AND P.C. SRIVASTAVA}

\author{
Department of Soil Science; College of Agriculture; Govind Ballabh Pant University of Agriculture and \\ Technology Pantnagar, Udham Singh Nagar, Uttarakhand-263145
}

Received: August, 2020; Revised accepted: September, 2020

\begin{abstract}
A GPS based soil survey was conducted in nine blocks of Chamoli district of Uttarakhand $(n=300)$ to evaluate the status of extractable macro- and micro-nutrients and to relate them with general soil properties. Soil texture ranged from sandy loam to clay loam, $\mathrm{pH}$ from 4.8 to 8.29 , electrical conductivity from 0.170 to $5.431 \mathrm{dSm}^{-1}$ and organic carbon content from 3.14 to $30.72 \mathrm{~g} \mathrm{~kg}^{-1}$ soil. Among the macro-nutrients, Olsen's and Bray's extractable $P$ varied from 1.41 to $47.20 \mathrm{mg} \mathrm{kg}^{-1}$ soil, neutral normal ammonium acetate extractable $\mathrm{K}$ content from 24.82 to $269.1 \mathrm{mg} \mathrm{kg}^{-1}$ soil. Exchangeable Ca and Mg content varied from 20 to $1620 \mathrm{mg} \mathrm{kg}^{-1}$ and 12 to $288 \mathrm{mg} \mathrm{kg}^{-1}$ soil, respectively. The content of $0.15 \% \mathrm{CaCl}_{2}$ extractable S content varied from 1.23 to 26.64 $\mathrm{mg} \mathrm{kg}^{-1}$ soil. The DTPA extractable $\mathrm{Zn}, \mathrm{Cu}, \mathrm{Fe}, \mathrm{Mn}$ content varied from 0.09 to $15.41,0.08$ to $9.03,3.13$ to 84.22 and 1.93 to $54.96 \mathrm{mg} \mathrm{kg}^{-1}$ soil, respectively. Hot water-soluble $B$ content varied from 0.23 to $2.61 \mathrm{mg} \mathrm{kg}^{-1}$ soil while ammonium oxalate ( $\mathrm{pH}$ 3.3) extractable Mo content varied from 0.18 to $1.36 \mathrm{mg} \mathrm{kg}^{-1}$ soil. Simple correlation showed that soil $\mathrm{pH}$ had a significant and positive correlation with soil extractable $\mathrm{P}, \mathrm{Ca}, \mathrm{S}, \mathrm{B}$ and Mo but a negative one with extractable $\mathrm{Cu}$, Fe and Mn. Soil EC had a significant and positive correlation with extractable $P, K, M g, S, F e, B$ and Mo. Soil organic carbon had a significant and positive correlation with extractable K. On the basis of calculated nutrient indices (N.I.), the soils of Chamoli district were low in soil extractable $\mathrm{S}$, medium in extractable $\mathrm{K}$ and $\mathrm{Zn}$, high in organic carbon content, extractable $P, \mathrm{Ca}, \mathrm{Mg}, \mathrm{Cu}, \mathrm{Fe}$, $\mathrm{Mn}, \mathrm{B}$ and $\mathrm{Mo}$ with sporadic cases of $\mathrm{Zn}, \mathrm{Cu}$ and $\mathrm{B}$ deficiency.
\end{abstract}

Keywords: General soil properties, macro-nutrients, micro-nutrients and nutrient index

\section{INTRODUCTION}

Soil fertility refers to the inherent capacity of a soil to supply essential nutrients to plants in adequate and right proportion for the optimum growth and it is one of the key components to determine soil productivity. Management of the fertility of Indian soil is a priority for sustainable production to feed its burgeoning population. Proper management of soil fertility demands a careful identification of current nutrient deficiencies and regular monitoring of changes in soil fertility to predict the emerging deficiencies in a region. Macronutrients $(N, P, K$, $\mathrm{Ca}, \mathrm{Mg}, \mathrm{S})$ and micronutrients (Zn, $\mathrm{Fe}, \mathrm{Cu}, \mathrm{Mn}$, $B$, Mo) control soil fertility. Owing to imbalanced and inadequate use of fertilizers with low efficiency of other inputs, the response of chemical fertilizers (nutrients) has also declined under intensive cultivation in recent years. The inherent variation in nutrients supply is a natural phenomenon and some of these nutrients may be sufficient while others may turn deficient. These deficiencies need to be alleviated through sound and proven practices to sustain food production at a reasonable level. Thus, management of soil health vis-à-vis nutrient management is one of the key factors in achieving high and sustainable productivity. In Uttarakhand the major soil zones are Hill soil, Bhabar soils and Tarai and agriculture land is very limited. In northern part of the state the soils are susceptible to erosion. The major crops grown in the hills are wheat, paddy, mandua, ramdana and potato. Therefore, the survey of Chamoli district was undertaken to assess the soil fertility in relation to status of available nutrients.

\section{MATERIALS AND METHODS}

The study area belongs to Chamoli district of Uttarakhand state between $30.42^{\circ} \mathrm{N}$ and $79.33^{\circ}$ $S$ latitude and longitude respectively. As the elevation of the district ranges from $800 \mathrm{~m}$ to $8,000 \mathrm{~m}$ above sea level the climate of the district vary largely depending on the altitude. The winter season is from about mid November to March. As most of the region is situated on the southern slopes of the outer Himalayas, monsoon currents can enter through the valley, the rainfall being heaviest in the 
monsoon from June to September. The district experienced a maximum temperature of $34^{\circ}$ celcius and a minimum temperature of $0^{0}$ celcius. For the Administrative convenience, the district has been divided into 9 developmental blocks viz.Dasoli, Garsain, Deval, Ghat, Joshimath, Karnaprayag, Naryanbagar, Pokhari and Tharali. Global Positioning System (GPS) based soil samples were collected from nine developmental blocks of Chamoli district of Uttarakhand at $0-15 \mathrm{~cm}$ depth. Soil $\mathrm{pH}$ was determined in soil-water suspension (1:2) using a combined glass electrode equipped $\mathrm{pH}$ meter (Jackson, 1973). Soil electrical conductivity was determined in the supernatants of soil water suspensions (1:2) with the help of a conductivity meter and the values were expressed as $\mathrm{dSm}^{-1}$ at 25 C. Soil organic carbon content in the soil samples was determined by modified Walkley and Black method (Jackson, 1973). Soil $\mathrm{CaCO}_{3}$ was determined by acid neutralization method. In neutral to alkaline soils, $\mathrm{P}$ was extracted by $0.5 \mathrm{M} \mathrm{NaHCO}_{3}(\mathrm{pH} 8.5)$ as described by Olsen et al. (1954) while in acidic soils (pH 4.5-5.5), $\mathrm{P}$ was extracted by $0.03 \mathrm{~N} \mathrm{NH}_{4} \mathrm{~F}+0.025 \mathrm{~N} \mathrm{HCl}$ as described by Bray and Kurtz (1945). Soil exchangeable $\mathrm{K}, \mathrm{Ca}$ and $\mathrm{Mg}$ were extracted using $1 \mathrm{~N}$ ammonium acetate $(\mathrm{pH}$ 7.0) and determined by flame photometry and versene titration method, respectively. Soil $S$ was extracted with $0.15 \% \mathrm{CaCl}_{2}$ and determined turbidimetrically (Chesnin and Yien, 1951). Soil $\mathrm{Zn}, \mathrm{Cu}, \mathrm{Fe}$ and $\mathrm{Mn}$ were extracted by DTPA (pH 7.3) as described by Lindsay and Norwell (1978) and determined on atomic absorption spectrophotometer. Hot water-soluble $B$ in the soil samples was extracted by following the method of Berger and Troug (1939) and determined by Azomethane $\mathrm{H}$ method. Molybdenum in the soil samples was extracted in $1 \mathrm{M}$ ammonium oxalate $(\mathrm{pH}$ 3.3) and determined using a colorimetric method (Grigg, 1953). Soil samples were categorized into low, medium and high categories for different nutrients following the criteria adopted by Bungla et al. (2019). Based on the number of samples in each category for a given nutrient the nutrient index (NI) value was calculated as:

Nutrient index $(\mathrm{NI})=\left[\left(\mathrm{N}_{\mathrm{L}} \times 1\right)+\left(\mathrm{N}_{\mathrm{M}} \times 2\right)+\left(\mathrm{N}_{\mathrm{H}} \mathrm{X}\right.\right.$ 3)]/ (100)

Where, $\mathrm{N}_{\mathrm{L}}, \mathrm{N}_{\mathrm{M}}$ and $\mathrm{N}_{\mathrm{H}}$ are indicating the number of soil samples in low, medium and high categories, respectively. Accordingly, the areas with nutrient index value $>2.33$ were considered high, those with $\mathrm{NI}$ between 1.67 to 2.33 were considered medium and those with values $<1.67$ were regarded as low in the native supply of that nutrient (Ramamoorthy and Bajaj, 1969).For statistical analysis, simple correlation analysis was done as per the statistical procedure outlined by Snedecor and Cochran (1967). The test of significance was performed both at $p \leq 0.05$ and $\leq 0.01$. The statistical analysis of the data was done with the help of a computer.

\section{RESULTS AND DISCUSSION}

\section{General soil properties}

The soils of Chamoli districts varied from loamy sand to sandy clay loam in texture. These soils were acidic to slightly alkaline (4.81-8.29) in reaction (Table 1). The highest mean value of $\mathrm{pH}$ (6.88) was observed in Karnaprayag block. Acidic soil pH in many blocks could be related to high organic $\mathrm{C}$ content releasing some organic acids upon decomposition resulting low $\mathrm{pH}$ in soils of lower buffering capacities (Aziz et al. 2012). The electrical conductivity of the Chamoli district ranged from 0.17 to $5.43 \mathrm{dSm}^{-1}$ and the highest average value was observed in Pokhari block $\left(1.21 \mathrm{dSm}^{-1}\right)$. The organic carbon content of Chamoli district ranged from 3.14 to $30.72 \mathrm{~g}$ $\mathrm{kg}^{-1}$ and the highest value was noticed in Dasoli block $\left(20.20 \mathrm{~g} \mathrm{~kg}^{-1}\right)$. The organic carbon accumulation in soil may also be attributed to better root biomass in legume crop (Shah et al. 2018). 
Table 1: General properties of Chamoli district soils

\begin{tabular}{|c|c|c|c|c|c|}
\hline Blocks & Texture & $\mathrm{pH}(1: 2)$ & $\mathrm{EC}\left(\mathrm{dSm}^{-1}\right)$ & $\mathrm{OC}\left(\mathrm{g} \mathrm{kg}^{-1}\right)$ & Free lime $(\%)$ \\
\hline Deval & $\begin{array}{l}\text { Loamy sand- clay } \\
\text { loam }\end{array}$ & $\begin{array}{c}5.32-7.16 \\
(5.93)^{*}\end{array}$ & $\begin{array}{c}0.22 \text { to } 1.62 \\
(0.60)\end{array}$ & $\begin{array}{c}3.49-24.31 \\
(14.38)\end{array}$ & Traces \\
\hline Tharali & $\begin{array}{l}\text { Loamy sand- } \\
\text { Sandy clay loam }\end{array}$ & $\begin{array}{l}5.25-7.25 \\
(6.06)\end{array}$ & $\begin{array}{l}0.24 \text { to1.21 } \\
(0.60)\end{array}$ & $\begin{array}{l}6.64-29.90 \\
(16.18)\end{array}$ & Traces \\
\hline Naryanbagar & $\begin{array}{l}\text { Sandy loam- } \\
\text { Clay loam }\end{array}$ & $\begin{array}{c}4.85-8.09 \\
(6.58)\end{array}$ & $\begin{array}{c}0.30 \text { to } 1.69 \\
(0.88)\end{array}$ & $\begin{array}{c}7.52-26.75 \\
(16.58)\end{array}$ & Tr. to 6.08 \\
\hline Karnaprayag & $\begin{array}{l}\text { Loamy sand- Clay } \\
\text { loam }\end{array}$ & $\begin{array}{l}5.84-8.29 \\
\quad(6.88)\end{array}$ & $\begin{array}{l}0.30-2.41 \\
(1.03)\end{array}$ & $\begin{array}{l}5.77-26.23 \\
(14.87)\end{array}$ & Tr. to 6.2 \\
\hline Pokhari & $\begin{array}{l}\text { Loamy sand- Sandy } \\
\text { clay loam }\end{array}$ & $\begin{array}{l}5.25-7.33 \\
\quad(6.35)\end{array}$ & $\begin{array}{c}0.38-5.43 \\
(1.21)\end{array}$ & $\begin{array}{l}5.77-24.65 \\
(15.36)\end{array}$ & Traces \\
\hline Ghat & $\begin{array}{c}\text { Sandy clay loam- silty } \\
\text { clay loam }\end{array}$ & $\begin{array}{c}5.55-7.27 \\
(6.23)\end{array}$ & $\begin{array}{c}0.17 \text { to } 1.42 \\
(0.71)\end{array}$ & $\begin{array}{c}6.82-27.45 \\
(18.42)\end{array}$ & Traces \\
\hline Garsain & $\begin{array}{l}\text { Loamy sand-clay } \\
\text { loam }\end{array}$ & $\begin{array}{l}5.12-7.24 \\
\quad(6.31)\end{array}$ & $\begin{array}{c}0.33 \text { to } 1.23 \\
(0.74)\end{array}$ & $\begin{array}{c}11.54-27.45 \\
(18.94)\end{array}$ & Traces \\
\hline Dasoli & $\begin{array}{l}\text { Sandy loam- Sandy } \\
\text { clay loam }\end{array}$ & $\begin{array}{l}5.65-7.17 \\
\quad(6.30)\end{array}$ & $\begin{array}{c}0.29 \text { to } 1.23 \\
(0.67)\end{array}$ & $\begin{array}{l}3.14-30.25 \\
(20.20)\end{array}$ & Traces \\
\hline Joshi math & $\begin{array}{l}\text { Loamy sand-Sandy } \\
\text { clay loam }\end{array}$ & $\begin{array}{l}4.18-8.15 \\
(6.18)\end{array}$ & $\begin{array}{c}0.34 \text { to } 1.61 \\
(0.89)\end{array}$ & $\begin{array}{l}4.54-27.63 \\
(16.60)\end{array}$ & Tr. to 5.02 \\
\hline $\begin{array}{l}\text { Entire Chamoli } \\
\text { district }\end{array}$ & $\begin{array}{l}\text { Loamy sand-sandy } \\
\text { clay loam }\end{array}$ & $\begin{array}{c}4.81-8.29 \\
(6.29)\end{array}$ & $\begin{array}{c}0.17-5.43 \\
(0.80)\end{array}$ & $\begin{array}{c}3.14-30.72 \\
(16.72)\end{array}$ & Tr. to 6.2 \\
\hline
\end{tabular}

\section{Status of macro-nutrients}

The extractable $P$ concentration varied from 1.41 to $47.20 \mathrm{mg} \mathrm{kg}^{-1}$ with a mean value of $10.82 \mathrm{mg} \mathrm{kg}^{-1}$ in soils of Chamoli district and the highest mean value was noticed in Naryanbagar block (19.74 mg kg${ }^{-1}$ ). The extent of $P$ deficiency were 5, 20, 13.3, 23.3 and 10.0 percent in Deval, Tharali, Pokhari and Garsain blocks, respectively with an overall deficiency of $9.3 \%$ for the entire district. The extractable $\mathrm{K}$ content ranged from 24.82 to $269.11 \mathrm{mg} \mathrm{kg}^{-1}$ with a mean value of $117.47 \mathrm{mg} \mathrm{kg}^{-1}$. The highest average extractable $\mathrm{K}$ content was observed in Joshimath block $\left(172.50 \mathrm{mg} \mathrm{kg}^{-1}\right)$. Percent soil samples deficient in extractable $\mathrm{K}$ were $20.0,30.0,3.3$ and $6.7 \%$ in Tharali, Naryanbagar, Pokhari and Dasoli blocks, respectively with an overall deficiency of $7.0 \%$ for the whole district. The exchangeable $\mathrm{Ca}$ content ranged from 20 to $1620 \mathrm{mg} \mathrm{kg}^{-1}$ with a mean value of $617.26 \mathrm{mg} \mathrm{kg}{ }^{-1}$ while the exchangeable Mg content in the soils of Chamoli district of Uttarakhand ranged from 12 to $288 \mathrm{mg}$ $\mathrm{kg}^{-1}$ with a mean value of $59.88 \mathrm{mg} \mathrm{kg}^{-1}$. The highest average extractable $\mathrm{Ca}$ content was found in Karnaprayag block (880.6 mg kg ${ }^{-1}$ ) and highest average extractable $\mathrm{Mg}$ content was reported in the Pokhari block $\left(110.4 \mathrm{mg} \mathrm{kg}^{-1}\right)$. In the entire Chaomoli district, only 5.6 and $2.0 \%$ soil samples were low in exchangeable $\mathrm{Ca}$ and $\mathrm{Mg}$, respectively. The extractable $S$ in the soils of
Chamoli district of Uttarakhand ranged from 1.23 to $26.64 \mathrm{mg} \mathrm{kg}^{-1}$ with a mean value of $7.92 \mathrm{mg}$ $\mathrm{kg}^{-1}$. Percent soil samples deficient in soil extractable $S$ were 40.0, 77.5, 90.0, 86.7, 60.0, 63.3, 93.3 and $100.0 \%$ in Deval, Tharali, Naryanbagar, Karnaprayag, Pokhari, Ghat, Garsain and Joshimath blocks, respectively with an overall deficiency of 77.6 percent for the entire Chamoli district. Low $S$ status in these soils could be ascribed to their very high altitude and low temperature with a probable low $\mathrm{S}$ mineralization and mineralized $S$ was likely to be washed away from coarse textured soil due to snow melting in summers followed by rainy season.

\section{Status of micro-nutrients}

The DTPA extractable $\mathrm{Zn}$ content ranged from 0.09 to $15.41 \mathrm{mg} \mathrm{kg}^{-1}$ and the highest average $\mathrm{Zn}$ content was observed in Naryan bagar block (3.96 mg kg-1). The extent of $\mathrm{Zn}$ deficiency in different blocks were 5.0, 15.0, 10.0, 13.3, 6.6 and $10.0 \%$ in Deval, Tharali, Naryanbagar, Karnaprayag, Pokhari and Garsain blocks, respectively with an overall deficiency of $8.0 \%$ for the district. Athokpam et al. (2013) also observed similar results where the DTPA extractable $\mathrm{Zn}$ content in the surface soils of Senapati district of Manipur varied from 1.30 to $4.9 \mathrm{mg} \mathrm{kg}^{-1}$. The DTPA extractable $\mathrm{Cu}$ content ranged from 0.08 to $9.03 \mathrm{mg} \mathrm{kg}^{-1}$ and percent 
Table 2: Extractable macronutrient status $\left(\mathrm{mg} \mathrm{kg}^{-1}\right)$ in soils of Chamoli district

\begin{tabular}{ccccccc|}
\hline Blocks & Extractable P & Extractable K & Extractable Ca & Extractable Mg & Extractable S \\
\hline Deval & $1.41-15.51$ & $54.1-232.3$ & $220-920$ & $12-120$ & $5.57-26.64$ \\
& $(6.19)^{*}$ & $(115.6)$ & $(570.5)$ & $(40.2)$ & $(12.06)$ \\
Tharali & $1.59-26.47$ & $42.7-259.1$ & $160-1440$ & $12-132$ & $5.57-21.07$ \\
& $(5.58)$ & $(92.9)$ & $(726.5)$ & $(47.7)$ & $(8.80)$ \\
Naryanbagar & $3.97-47.20$ & $24.8-250.2$ & $60-1460$ & $12-204$ & $3.09-22.31$ \\
& $(19.74)$ & $(83.2)$ & $(617.3)$ & $(57.6)$ & $(7.16)$ \\
Karnaprayag & $3.36-35.00$ & $54.1-269.1$ & $60-1620$ & $12-204$ & $1.23-17.97$ \\
& $(19.72)$ & $(88.5)$ & $(880.6)$ & $(56.8)$ & $(6.65)$ \\
Pokhari & $1.62-26.37$ & $45.1-197.6$ & $20-1400$ & $24-288$ & $2.47-20.45$ \\
& $(10.43)$ & $(115.7)$ & $(603.3)$ & $(110.4)$ & $(9.72)$ \\
Ghat & $1.59-23.26$ & $54.1-264.1$ & $140-1440$ & $12-168$ & $3.71-24.16$ \\
& $(8.43)$ & $(119.9)$ & $(608.0)$ & $(56.8)$ & $(10.30)$ \\
Garsain & $1.95-29.31$ & $31.2-255.2$ & $80-1040$ & $12-192$ & $1.85-12.39$ \\
& $(9.84)$ & $(125.5)$ & $(614.0)$ & $(54.4)$ & $(5.57)$ \\
Dasoli & $3.14-26.52$ & $26.3-238.8$ & $200-1020$ & $12-240$ & $3.09-13.01$ \\
& $(11.21)$ & $(133.5)$ & $(470.6)$ & $(54.4)$ & $(6.50)$ \\
Joshi math & $1.62-26.26$ & $57.5-252.2$ & $80-1240$ & $12-144$ & $1.23-9.91$ \\
Entire Chamoli & $(9.86)$ & $(172.5)$ & $(487.0)$ & $(59.7)$ & $(4.16)$ \\
district & $1.41-47.20$ & $24.8-269.1$ & $20-1620$ & $12-288$ & $1.23-26.64$ \\
\hline
\end{tabular}

soil samples deficient in extractable $\mathrm{Cu}$ were 7.5 and $6.67 \%$ for Deval and Narya bagar blocks, respectively with an overall deficiency of only 2.3 $\%$ for the district. The highest average $\mathrm{Cu}$ content was recorded in the Pokhari block $(2.02 \mathrm{mg} \mathrm{kg}$ $\left.{ }^{1}\right)$.Similar range was also reported by Kamble et al. (2013) for the Ahmednagar district of Maharashtra. The DTPA extractable Fe and $\mathrm{Mn}$ content in the soils of Chamoli district varied from 3.13 to 84.22 and 1.93 to $54.96 \mathrm{mg} \mathrm{kg}^{-1}$ soil, respectively and only $3.3 \%$ soil samples were low in extractable $\mathrm{Fe}$ and $\mathrm{Mn}$ in Karanprayag block with an overall deficiency of $0.33 \%$ soils for both nutrients in the district. The highest average Fe content $\left(44.97 \mathrm{mg} \mathrm{kg}^{-1}\right)$ in Joshimath block and the highest average $\mathrm{Mn}$ content was observed in Pokhari block (23.26 $\left.\mathrm{mg} \mathrm{kg}{ }^{-1}\right)$. A similar range of soil extractable $\mathrm{Mn}$ had been reported by Thakor et al. (2014). Hot water-soluble $B$ ranged from 0.23 to $2.61 \mathrm{mg} \mathrm{kg}^{-1}$ with a mean value of $0.96 \mathrm{mg} \mathrm{kg}^{-1}$. The highest average soil extractable $\mathrm{B}$ content was recorded in Joshimath block $\left(1.31 \mathrm{mg} \mathrm{kg}^{-1}\right)$. Among different blocks, only $2.5 \%$ soil samples of Deval block were low in B with an overall deficiency of $0.33 \%$ for the entire district. Soil extractable Mo content varied from 0.18 to $1.36 \mathrm{mg} \mathrm{kg}^{-1}$ with a mean value of $0.62 \mathrm{mg} \mathrm{kg}^{-1}$ and no soil sample in the entire district was low in extractable Mo. The highest average value of extractable Mo content was observed in Karnaprayag block $\left(0.80 \mathrm{mg} \mathrm{kg}^{-1}\right)$. Shukla et al. (2015) also reported a range of 0.12 to $1.84 \mathrm{mg}$ extractable $\mathrm{Mo} \mathrm{kg}^{-1}$ soil for U.S. Nagar district of Uttarakhand.In general, high availability of micronutrients in these soils could be ascribed to high organic matter content which helped to maintain high supply of micronutrients due to chelating action of humic substances which also could prevent their fixation, precipitation, oxidation and leaching in soils (Bungla et al. 2019). Besides this, the soils of medium and fine texture also maintained higher contents of extractable macroand micro-nutrients as compared to coarse textured soils having low content of soil colloids.

\section{Correlation among soil properties and extractable macro- and micro-nutrients}

Soil $\mathrm{pH}$ showed a significant and positive correlation with extractable $P(r=0.652)$, exchangeable $\mathrm{Ca}(r=0.211)$ at $\mathrm{p}<0.01$ and $\mathrm{S}(\mathrm{r}$ $=0.120)$ at $p<0.05$ but a negative correlation with $\mathrm{Cu}(r=-0.511)$ at $\mathrm{p}<0.01$, Fe $(r=-0.143)$, $\mathrm{Mn}(-0.117)$ at $p<0.05$. This relationship might be due to the presence of more than $50 \%$ of phosphorus in organic forms and after the decomposition of organic matter as humus is formed which forms complex with $\mathrm{Al}$ and $\mathrm{Fe}$ and that is a protective cover for $\mathrm{P}$ fixation with $\mathrm{Al}$ and $\mathrm{Fe}$ thus reduce phosphorus adsorption/ phosphate fixation (Tisdale et al., 1997). 
Table 3: Extractable micronutrient status $\left(\mathrm{mg} \mathrm{kg}^{-1}\right)$ in soils of Chamoli district

\begin{tabular}{cccccccc|c|}
\hline Blocks & $\begin{array}{c}\text { Extractable } \\
\mathrm{Zn}\end{array}$ & $\begin{array}{c}\text { Extractable } \\
\mathrm{Cu}\end{array}$ & $\begin{array}{c}\text { Extractable } \\
\mathrm{Fe}\end{array}$ & $\begin{array}{c}\text { Extractable } \\
\mathrm{Mn}\end{array}$ & $\begin{array}{c}\text { Extractable } \\
\mathrm{B}\end{array}$ & $\begin{array}{c}\text { Extractable } \\
\mathrm{Mo}\end{array}$ \\
\hline \multirow{2}{*}{ Deval } & $0.55-15.41$ & $0.13-8.73$ & $9.87-64.78$ & $4.47-52.69$ & $0.23-2.04$ & $0.18-1.00$ \\
& $(2.64) *$ & $(1.36)$ & $(38.80)$ & $(15.42)$ & $(0.76)$ & $(0.55)$ \\
Tharali & $0.35-8.14$ & $0.24-6.72$ & $12.12-71.42$ & $2.05-48.66$ & 0.50 to 0.70 & $0.27-1.09$ \\
& $(1.77)$ & $(1.24)$ & $(39.02)$ & $(12.14)$ & $(0.91)$ & $(0.58)$ \\
Naryanbagar & $0.09-13.10$ & $0.08-6.82$ & $7.96-74.88$ & $4.49-46.86$ & $0.34-2.11$ & $0.18-1.27$ \\
& $(3.96)$ & $(1.96)$ & $(33.98)$ & $(14.76)$ & $(0.94)$ & $(0.66)$ \\
Karnaprayag & $0.35-6.23$ & $0.12-7.14$ & $3.13-60.47$ & $1.93-52.64$ & $0.42-2.61$ & $0.27-1.36$ \\
& $(2.05)$ & $(1.78)$ & $(27.53)$ & $(19.14)$ & $(0.95)$ & $(0.80)$ \\
Pokhari & $0.45-13.07$ & $1.04-4.92$ & $10.23-70.69$ & $6.85-54.96$ & $0.38-2.27$ & $0.27-1.09$ \\
& $(2.83)$ & $(2.02)$ & $(39.65)$ & $(23.26)$ & $(0.96)$ & $(0.65)$ \\
Ghat & $0.43-14.53$ & $0.25-3.27$ & $7.46-84.22$ & $6.10-53.08$ & $0.26^{-1} .84$ & $0.36-1.00$ \\
& $(3.18)$ & $(1.32)$ & $(42.75)$ & $(18.24)$ & $(0.72)$ & $(0.55)$ \\
Garsain & $0.39-8.16$ & $0.59-3.62$ & $9.83-74.36$ & $6.59-37.08$ & $0.30^{-1} .88$ & $0.36-1.09$ \\
& $(1.51)$ & $(1.75)$ & $(30.88)$ & $(14.25)$ & $(0.97)$ & $(0.61)$ \\
Dasoli & $0.56-6.10$ & $0.51-9.03$ & $10.36-71.28$ & $3.35-14.65$ & $0.46-2.46$ & $0.36-1.00$ \\
& $(1.95)$ & $(1.78)$ & $(36.71)$ & $(7.86)$ & $(1.04)$ & $(0.61)$ \\
Joshi math & $0.76-15.33$ & $0.37-1.92$ & $15.41-81.44$ & $4.69-24.52$ & $0.53-2.61$ & $0.18-1.36$ \\
Entire Chamoli & $(3.87)$ & $(0.96)$ & $(44.97)$ & $(11.55)$ & $(1.31)$ & $(0.63)$ \\
district & $0.09-15.41$ & $0.08-9.03$ & $3.13-84.22$ & $1.93-54.96$ & $0.23-2.61$ & $0.18-1.36$ \\
\hline
\end{tabular}

This showed that acidic soil $\mathrm{pH}$ become more conducive for leaching of $\mathrm{Ca}$ and $\mathrm{S}$. The negative correlation of soil $\mathrm{pH}$ with $\mathrm{Fe}$ indicates as soil $\mathrm{pH}$ increases there is a reduction in the availabilty of Fe. Similar results were reports by Chander et al. (2014) in vegetable growing soils of sub-humid and wet- temperate zones of Himachal Pradesh. Extractable Mn showed a significant and negative correlation with soil $\mathrm{pH}$ indicating that its availability is largely influenced by acidic nature of the soil. Similar results were reports by Chander et al. (2014) in vegetable growing soils of sub-humid and wet- temperate zones of Himachal Pradesh Soil EC showed a significant and positive correlation with extractable $P(r=0.266), K(r=0.227), M g(r=$ $0.261), S(r=0.274)$, Fe $(r=0.153), B(r=$ $0.159)$, Mo $(r=0.365)$ at $p<0.01$ indicating thereby higher solubility of these nutrients in soil solution. Soil organic carbon showed a significant and positive correlation with extractable $K(r=0.168)$ at $p<0.01$ and this behavior could be attributed to higher retention of $\mathrm{K}$ on exchange sites contributed by soil organic matter (Kakkar et al. 2020). Soil organic $\mathrm{C}$, however, showed a significant negative correlation with $\mathrm{Mn}(r=-0.133)$ at $p<0.05$ indicating formation of stable complexes of $\mathrm{Mn}$ with soil organic matter in these soils (Andrade et al. (2002).
Table 4: Correlation between soil properties and available nutrients in the soils of Chamoli district

\begin{tabular}{|c|c|c|c|}
\hline Nutrients & $\mathrm{pH}(1: 2)$ & $\mathrm{EC}\left(\mathrm{dSm}^{-1}\right)$ & $\begin{array}{l}\text { Organic carbon } \\
\left(\mathrm{g} \mathrm{kg}^{-1}\right)\end{array}$ \\
\hline$P$ & $0.652^{* x}$ & $0.266^{* *}$ & -0.017 \\
\hline K & 0.082 & $0.227^{* \pi}$ & $0.168^{* *}$ \\
\hline $\mathrm{Ca}$ & $0.211^{\star *}$ & 0.099 & 0.014 \\
\hline $\mathrm{Mg}$ & 0.033 & $0.261^{\star x}$ & -0.007 \\
\hline s & $0.120^{*}$ & $0.274^{* x}$ & -0.023 \\
\hline $\mathrm{Zn}$ & 0.012 & 0.085 & 0.057 \\
\hline $\mathrm{Cu}$ & $-0.511^{\star *}$ & -0.087 & 0.036 \\
\hline $\mathrm{Fe}$ & $-0.143^{x}$ & $0.153^{* x}$ & -0.042 \\
\hline $\mathrm{Mn}$ & $-0.117^{\star}$ & 0.010 & $-0.133^{x}$ \\
\hline B & $0.132^{*}$ & $0.159^{* x}$ & 0.074 \\
\hline Mo & $0.898^{x *}$ & $0.365^{x *}$ & -0.003 \\
\hline
\end{tabular}

${ }^{* *}$ Significant at $p \leq 0.01$ and ${ }^{*}$ Significant at $p \leq 0.05$

From this study, it can be concluded that soil texture of Chamoli district ranged from coarse to fine and had acidic to slightly alkaline soil reaction with high content of organic carbon. Soil $\mathrm{CaCO} 3$ was found only in traces in some blocks like Naryan bagar, Karna prayag and Joshimath blocks where the soil $\mathrm{pH}$ was above 7.5. On the basis of calculated nutrient index, the entire district was very low in $S$ particulary, in Joshimath block. The district was medium in $\mathrm{K}$ but high in $\mathrm{P}, \mathrm{Ca}$ and $\mathrm{Mg}$. Among micronutrients, supply of $\mathrm{Zn}$ was medium while rest micro-nutrients such as $\mathrm{Fe}, \mathrm{Zn}, \mathrm{Mn}, \mathrm{B}$ and $\mathrm{Mo}$ were sufficient. 


\section{ACKNOWLEDGEMENTS}

Authors are thankful to Project Coordinator, AICRP-Micronutrients, IISS, Bhopal

\section{REFERENCES}

Andrade, E.; Miyazawa, M.; Pavan, M. A. and de Oliveira, E. L. (2002) Effect of organic matter on manganese solubility.Brazilian Archives of Biology and Technology 45 (1): 17-20.

Athokpam, H.; Wani, S.H.; Kamel, D.; Singh, Athokpam, H.S.; Nongmalthem, J.; Kumar,D.; Singh,Y.K.; Naorem, B.S.; Devi, T.R. and Devi, L. (2013) Soil macroandmicro- nutrient status of Senapati district, Manipur (India). African Journal of Agricultural Research 8 (39): 4932 - 4936.

Aziz, M.A.; Aezum, A.T.; Mahdi, S.S. and Ali, T. (2012) Effect of integrated nutrient management on soil physical properties using soybean (Glycine $\max (\mathrm{L})$ Merill) as indicator crop under temperate condition. International Journal of Current Research 4(1): 203-207.

Berger, K.C. and Troug, E. (1939) Boron determination in soils and plants. Industrial and Engineering Chemistry, Analytical Edition 11: 540-545.

Bray, R.H. and Kurtz, L.T. (1945) Determination of total, organic and available forms of phosphorus in soils. Soil Science 59: 39-45.

Bungla, P.; Pachauri, S. P.; Srivastava, P.C.; Pathak, A. and Singh, R.K. (2019) Macroand micro-nutrients status in some soils of Pithoragarh district of Uttarakhand. Annals of Plant and Soil Research 21(2): 108-115.

Chander, G.; Sharma, S.; Sharma, V.; Verma, S.; Sharma, S. and Verma, T.S. (2014) Micronutrient cations status in vegetable growing soils of sub-humid and wettemperate zones of Himachal Pradesh. Himachal Journal of Agricultural Research 40(1): 79-83

Chesnin, L. and Yien, C.H. (1951) Turbidimetric determination of available sulphate. Soil Science Society of America Proceedings 15: 149-151.

Grigg, J.L. (1953) Determination of available molybdenum of soils. New Zealand Journal of Science and Technology 34: 405-414.

Jackson, M.L. (1973) Soil Chemical Analysis. Prentice Hall of India (P) Ltd., New Delhi. pp. 183-192.

Kakkar, R.; Tripathi D.; Chandel, S. and Sultanpuri, A. (2018) Distribution of Micronutrient Cations in relation to soil properties in Saproon valley of Solau for providing necessary facility to conduct this study.

district in North Western Himalaya. Annals of Plant and Soil Research 20(2): 143-147.

Kamble, P.N.; Kurhe, A.R.; Pondhe, G.P.; Gaikwad, V.B. and Baath, E. (2013).Soil nutrient analysis and their relationship with special reference to $\mathrm{pH}$ in Pravaranagar area, District Ahmednagar, Maharashtra, India. International Journal of Scientific \& Technology Research 2 (3) : 2277 - 8616.

Lindsay, W.L. and Norvell, W.A. (1978) Development of DTPA soil test for zinc, iron, manganese and copper. Soil Science Society of America Journal 42: 421-428.

Olsen, S.R.; Col, C.V.; Watanabe, F.S. and Dean, L.A. (1954) Estimation of available phosphorus in soils by extraction with bicarbonate, Circular of the United States Department of Agriculture 939, US Government Printing Office, Washington DC.

Ramamoorthy and Bajaj (1969) Available N, P and $\mathrm{K}$ status of Indian soils. Fertilizer News 14 (8): 24-28.

Shah, T.I.; Rai, A.P.; Mondal, A.K.; Samanta, A.; Kour, S.; Wali, P. and Dwivedi, M.C. (2018) Available Micronutrient Status of Mothbean Growing Soils of Poonch District (Jammu and Kashmir) in relation to Soil Properties. Journal of the Indian Society of Soil Science 66 (4): 436-439.

Shukla, A.K.; Srivastava, P.C.; Tiwari, P.K.; Prakash, C.; Patra, A.K.; Singh, P. and Pachauri, S.P. (2013) Mapping current micronutrients deficiencies in soils of Uttarakhand for precise micronutrient management. Indian Journal of Fertilizers 11(7): 52-63.

Snedecor, G. W. and Cochran, W. G. (1967) Statistical methods $5^{\text {th }}$ ed. Oxford and IBH. Publishing Company, Calcutta,

Thakor, K.M.; Dharaiya, N.; Singh, V.; Patel, A.; Mehmood, K.; and Kalubarme M.H. (2014) Spatial variability mapping of micronutrients to improve productivity using geoinformatics technology in Gujarat state, India.International Journal of Scientefic and Engineering Research 3(7): 2229 - 5618.

Tisdale, S.L., Nelson, W.L., Beaton, J.D. and Havlin, J.L. (1997) Soil Fertility and Fertilizers, $5^{\text {th }}$ Edition, Macmillan Publishing Co., New Delhi. 